\title{
Comparative Taxonomy of the Genus Torulopsis Berlese
}

\author{
By ANNA KOCKOVÁ-KRATOCHVÍLOVÁ \\ Institute of Chemistry of the Slovak Academy of Sciences, Bratislava, CSSR
}

(Received I3 March 1973)

\begin{abstract}
SUMMARY
A set of I 2I strains of yeasts, originally described as Torulopsis, was studied by means of 63 morphological, physiological and serological characters and was subjected to numerical analysis. The matching coefficient of Sokal and Michener and the average linkage cluster analysis allowed the grouping of strains into nine phenons, formed on the $80 \%$ similarity level: stellata, dattila, colliculosa, molischiana, pinus-schatavii-glabrata, versatilis, gropengiesseri, wickerhamii-kruisiicandida and holmii. Resulting data agreed with published results of GC content in DNA.
\end{abstract}

\section{INTRODUCTION}

The genus Torulopsis Berlese comprises yeast-like micro-organisms with globose, ovoid to elongate cells, which reproduce by multipolar budding. Pseudomycelium is absent or rudimentary. They form neither ascospores, teliospores, ballistospores nor arthrospores. Strains are white or cream-coloured; no carotenoid pigments are present. Extracellular polysaccharides do not give the iodine-starch reaction. Inositol is not utilized as a sole carbon source. Torulopsis colliculosa (Hartmann) Saccardo was designated as a type species of this genus. In the taxonomic study of Lodder (1970), 36 species of this genus were described, differing in the ability to ferment and assimilate mono- and oligo-saccharides.

Recently it has been suggested that these organisms can be haploid forms of heterothallic ascosporogenous yeasts. They spend their vegetative state in the haploid phase and after isolation from their natural habitat only one sexual type becomes selected. These forms can neither diploidize nor sporulate because of the absence of the opposite mating type required for conjugation. Our attempts to mate pure cultures of Torulopsis species, preserved in collection, were unsuccessful. Wickerham (I965) suggested mating naturally occurring and freshly isolated strains. It also often happens that homothallic haploid cultures enter collections as Torulopsis species, but then diploidize and sporulate, or perhaps eventually produce pseudomycelium.

This imperfect genus is thus very heterogeneous and will be dropped when perfect forms of all its species have been discovered. These perfect forms can be predicted by the similarity of phenotype or the DNA characteristics, but the actual recognition of sexual processes can be the only irrefutable evidence. Since the recognition of perfect forms of all known Torulopsis species is a very tedious and complicated task, much effort has been devoted to grouping the species on the basis of their phenotype (Spencer, Gorin \& Tulloch, 1970; Nakase \& Komagata, I97I ; Ondrušová, 1971 ; Campbell, 197I ; etc.).

This paper presents the results of the numerical re-evaluation of I 2 I strains of 46 different species on the basis of 63 characters, and a comparison with other kinds of taxonomic investigations. 


\section{METHODS}

Strains. The origin of strains used is given in Results. The majority were isolated from the surface of fruit bodies of various agarics, plants and other natural sources (KockováKratochvílová, Petrovová, Šandula \& Hronská, I964; Kocková-Kratochvílová, Šmarda \& Pokorná, 1965; Kocková-Kratochvílová \& Ondrušová, 1971). Other strains were received from collections, predominantly from $\mathrm{CBS},{ }^{*}$ as type cultures. The precise data of isolation are given in the Catalogue of Czechoslovak Yeast Collections, UJEP Brno, I968.

Character evaluations. The 63 characters evaluated for each of I 2 I strains are mostly given in Table I. The structure of the characters can be inferred from this Table. We used morphological, physiological, genetical and immunological methods as described in our previous paper (Kocková-Kratochvílová, Šandula, Vojtková-Lepšíková, Sedlárová \& Kasmanová, I969). Rabbit sera prepared against five different species were kindly supplied by Dr J. Šandula.

Coding of features for computation. Some features exist in two mutually exclusive (alternative, bimodal) states and were scored for computation as I or o, e.g. the assimilation or fermentation of sugars; other qualitative features were divided into more than two mutually exclusive (discontinuous) states, e.g. character of giant colonies and growth in liquid media. Multistate quantitative characters were divided into states according to the frequency distribution curves, e.g. cell sizes, radial growth rate and inhibition. The non-additive code in the $O$ and I scale was used for more than two state characters.

Computation. The similarity between strains was computed by the 'matching' coefficient method of Sokal \& Michener (1958) in which both positive and negative matches were assessed as similarity. This coefficient, $S_{\mathrm{SM}}$, was calculated from the formulae:

and

$$
S_{\mathrm{sM}}=\mathrm{I}-d_{j k}^{2}
$$

$$
d_{j k}^{2}=\frac{\stackrel{n}{\Sigma}\left(x_{j}-x_{k}\right)^{2}}{n}
$$

(which are valid for the o-I scale being used) where $x_{j}$ and $x_{k}$ are matches for strains $j$ and $k, n$ is the number of matches taken into the calculation, and $d_{j k}$ is the taxonomic distance between strains $j$ and $k$. The dendrogram was prepared by the method of unweighted average linkage (Sokal \& Sneath, 1963). The homogeneity of clusters was checked, using the $\chi^{2}$-test. Single phenons were characterized according to the percentage frequency of positive characters defined at the $80 \%$ similarity level (Goodfellow, 1971).

The calculations were programmed in Algol and carried out on the Gier III computer at the Institute of Technical Cybernetics of the Slovak Academy of Sciences, Bratislava.

Guanine and cytosine $(G C)$ content in $D N A$. We compared our results with the characteristics of DNA as found by Nakase \& Komagata (I97I). Dr T. Nakase kindly determined the GC content in DNA of twenty of our strains of species which were not investigated by Nakase \& Komagata.

* Abbreviations used for sources of cultures are: BUC̆SAV, Biological Institute of the Czechoslovak Academy of Sciences, Prague; CBS, Centraalbureau voor Schimmelcultures, Delft; CCY, Czechoslovak Collection of Yeasts, Bratislava; IFO, Institute of Fermentation, Osaka; LVHCH, Laboratory for Vitamin and Hormone Chemistry, Prague. 
RESULTS

\section{Formation of phenons}

We investigated I I strains of the genus Torulopsis and classified them into nine phenons at the $80 \%$ similarity level. Fig. I shows the scheme of this clustering. Phenon no. 2, dattila, was represented by three strains, phenon no. 4, molischiana, by only two strains and the first subphenon of no. 5, pinus, by three strains. These three minor phenons were not included in Table $\mathrm{I}$.

The new phenetic re-evaluation of some strains was not in agreement with the standard description of the genus Torulopsis mentioned in the introduction. Some of them produced ascospores or pseudomycelium (e.g. the group C), or chlamydospores (e.g. Torulopsis burgeffiana). The perfect forms were completely excluded; others were included in the clustering, but their relations to other genera were designated as A, B, C and D in Fig. I. All classified strains were similar on the common level $0 \cdot 758$. The phenons were named after the most frequently included or centroidal strains.

\section{Phenon stellata}

\section{Characteristics of phenons}

The strains assigned to the phenon stellata were: CCY 26-I3-I, Torulopsis bacillaris (CBS, 1947); CCY 26-13-2, T. bacillaris (CBS 843, 1964); CCY 26-10-3, T. stellata var. cambresieri (South Slovakia, 1958); CCY 26-10-6, T. stellata var. cambresieri (CBS I 58, 1964); CCY 26-19-2, T. famata (BU ČSAV 623, I958); and CCY 26-I I-I, T. kefyr (LVHCH, Prague, I943).

Cells were elongate with a surface/volume (S/V) quotient typical for haploid genotypes. They formed a sediment in liquid media. Giant colonies were smooth to semi-dull and their growth rate was high. Growth temperature range was 5 to $42{ }^{\circ} \mathrm{C}$. Some strains required external vitamins for growth. Sedimentation and autolysis were slow. Strains were mostly resistant to $0 \cdot \mathrm{I} \mu \mathrm{g}$ actidione/disc and $2 \%(\mathrm{w} / \mathrm{v})$ lactic acid, but strongly inhibited by $2 \%$ $(\mathrm{w} / \mathrm{v})$ tartaric acid. The TTC test was positive in the presence of succinate. Catalase activity was high. Strains exhibited different agglutination with the antisera used. Glucose and sucrose were fermented. Assimilation of $\mathrm{KNO}_{3}$ was negative.

\section{Phenon dattila}

The strains assigned to the phenon dattila were: CCY 26-6-I, Torulopsis dattila (CBS, 1947); CCY 26-6-2, T. dattila (CBS 137, I964); and CCY 26-5-I, T. rosei (CBS, 1947).

Cells were globose, ovoid to elongate; S/V quotients were typical for polyploid cells. Only sediment was formed in liquid media. Giant colonies were smooth, glistening or semidull; their growth rate was moderate. Strains grew well at $5{ }^{\circ} \mathrm{C}$, but not at $42{ }^{\circ} \mathrm{C}$. They tolerated I to $\mathrm{I} 2 \%(\mathrm{w} / \mathrm{v})$ ethanol in the medium. Osmophily was high. Sedimentation and autolysis were slow. Strains needed external vitamins for growth. Growth was not inhibited by $0 . \mathrm{I} \mu \mathrm{g}$ actidione $/$ disc, $2 \%(\mathrm{w} / \mathrm{v})$ lactic acid and $2 \%(\mathrm{w} / \mathrm{v})$ tartaric acid. The TTC test was positive in the presence of succinate, lactate and acetate. Catalase activity was moderate. Arbutin was split. All strains agglutinated with serum prepared against Torulopsis globosa. Glucose and sucrose were fermented; $\mathrm{KNO}_{3}$ was not assimilated.

\section{Phenon colliculosa}

The strains assigned to the phenon colliculosa were: CCY 26-7-I, Torulopsis colliculosa (CBS, I947); CCY 26-7-3, T. colliculosa (Evonymus, South Slovakia, I957); CCY 26-7-4, 

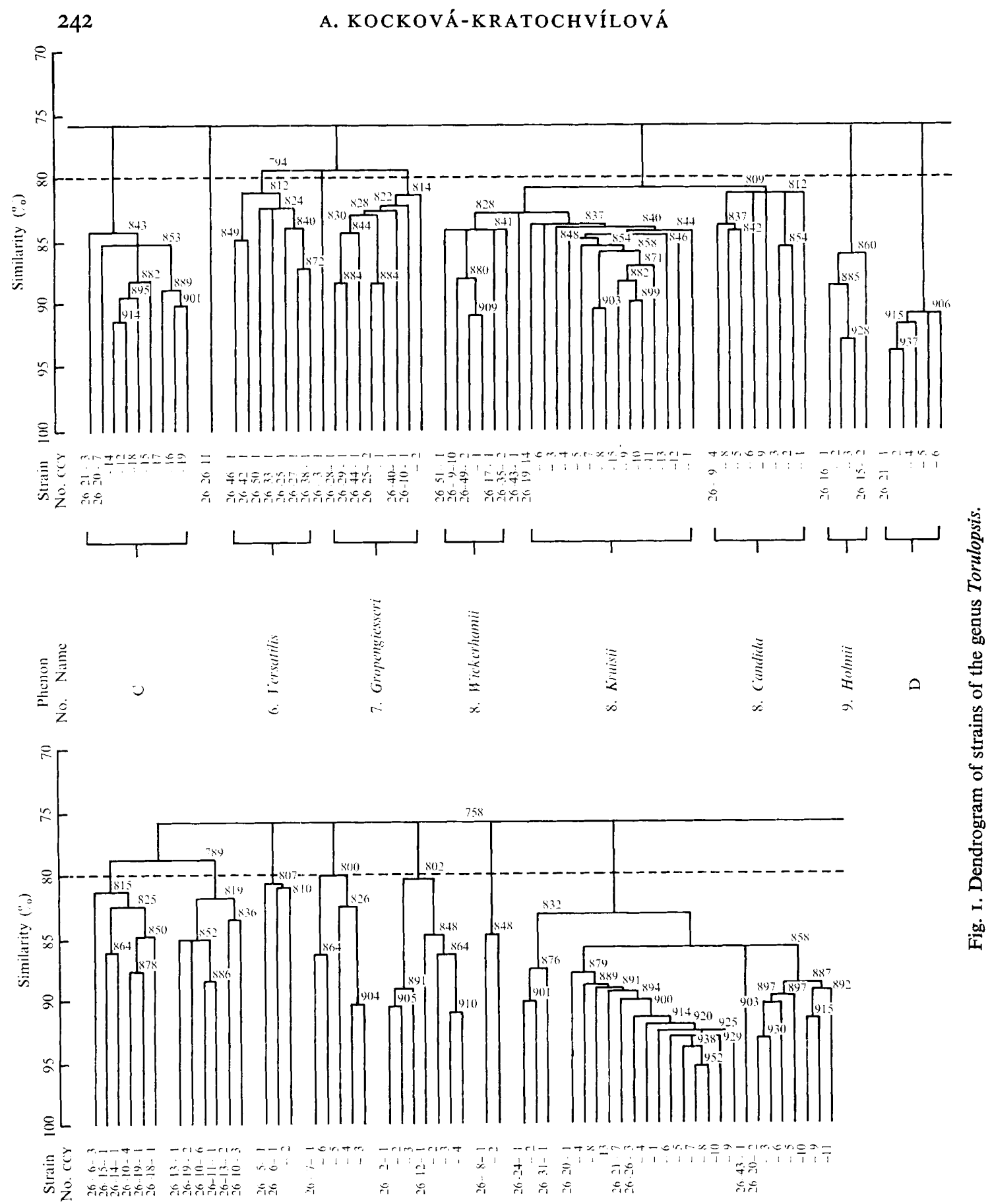
L 1
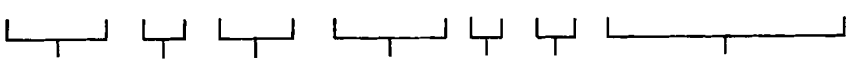

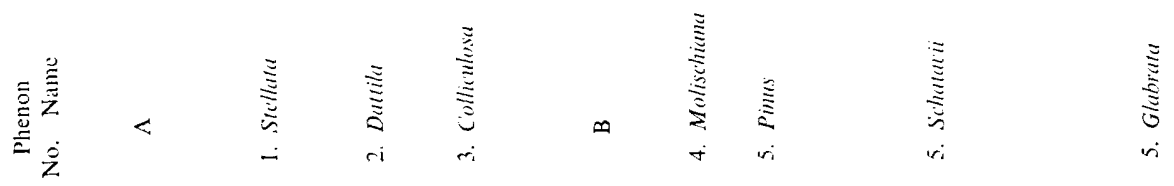

 
Taxonomy of the genus Torulopsis Berlese

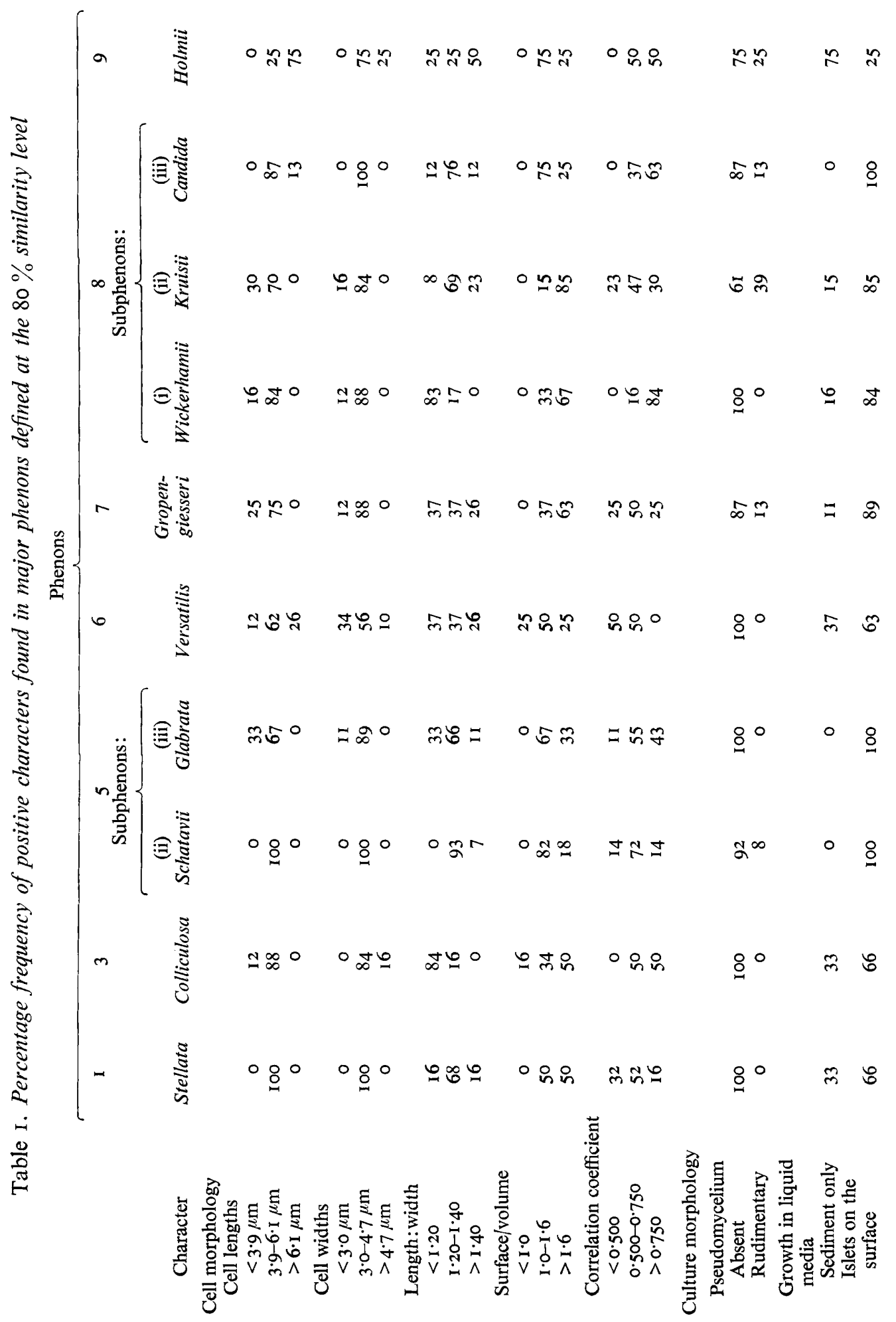




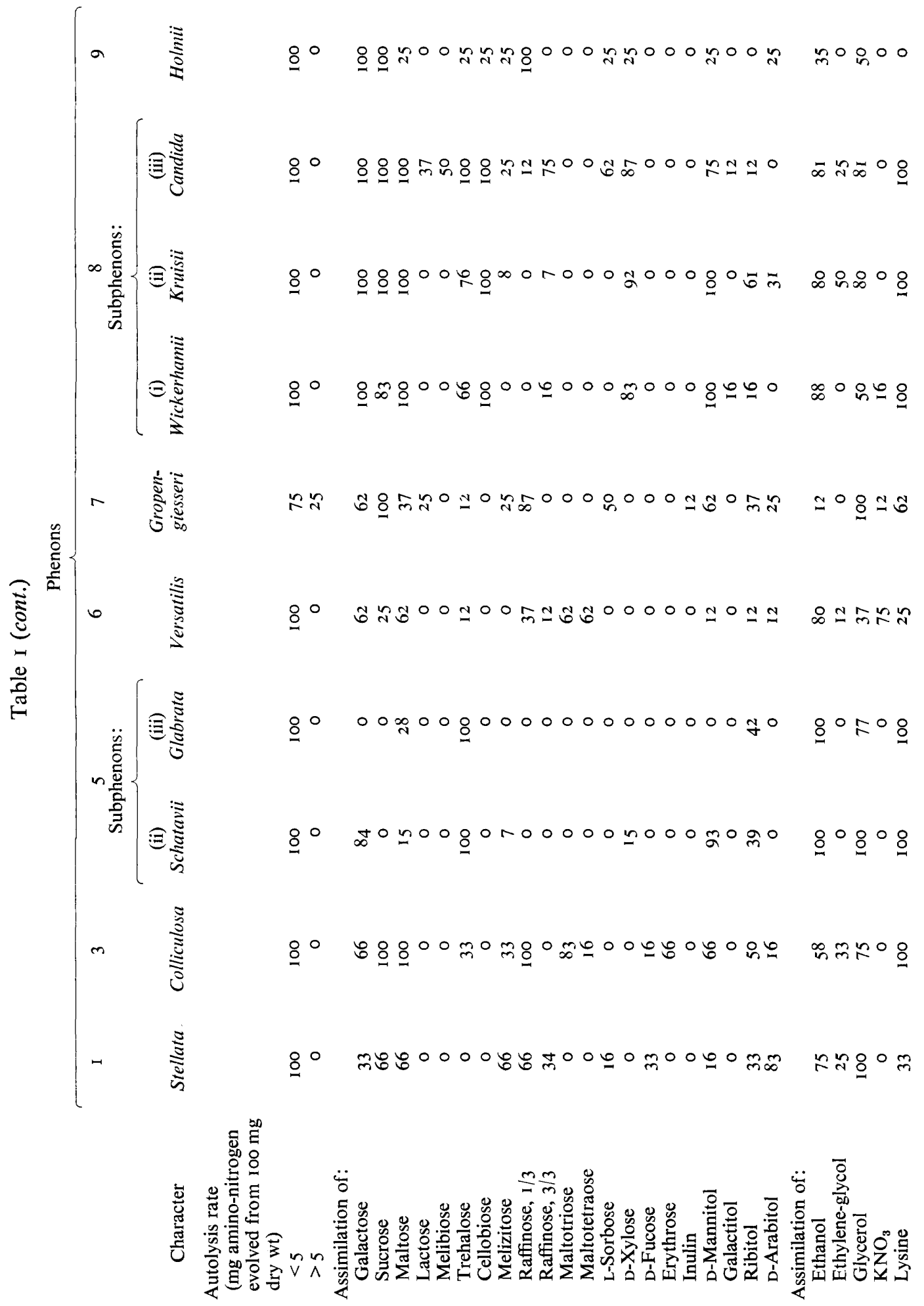


A. KOCKOVÁ-KRATOCHVÍLOVÁ

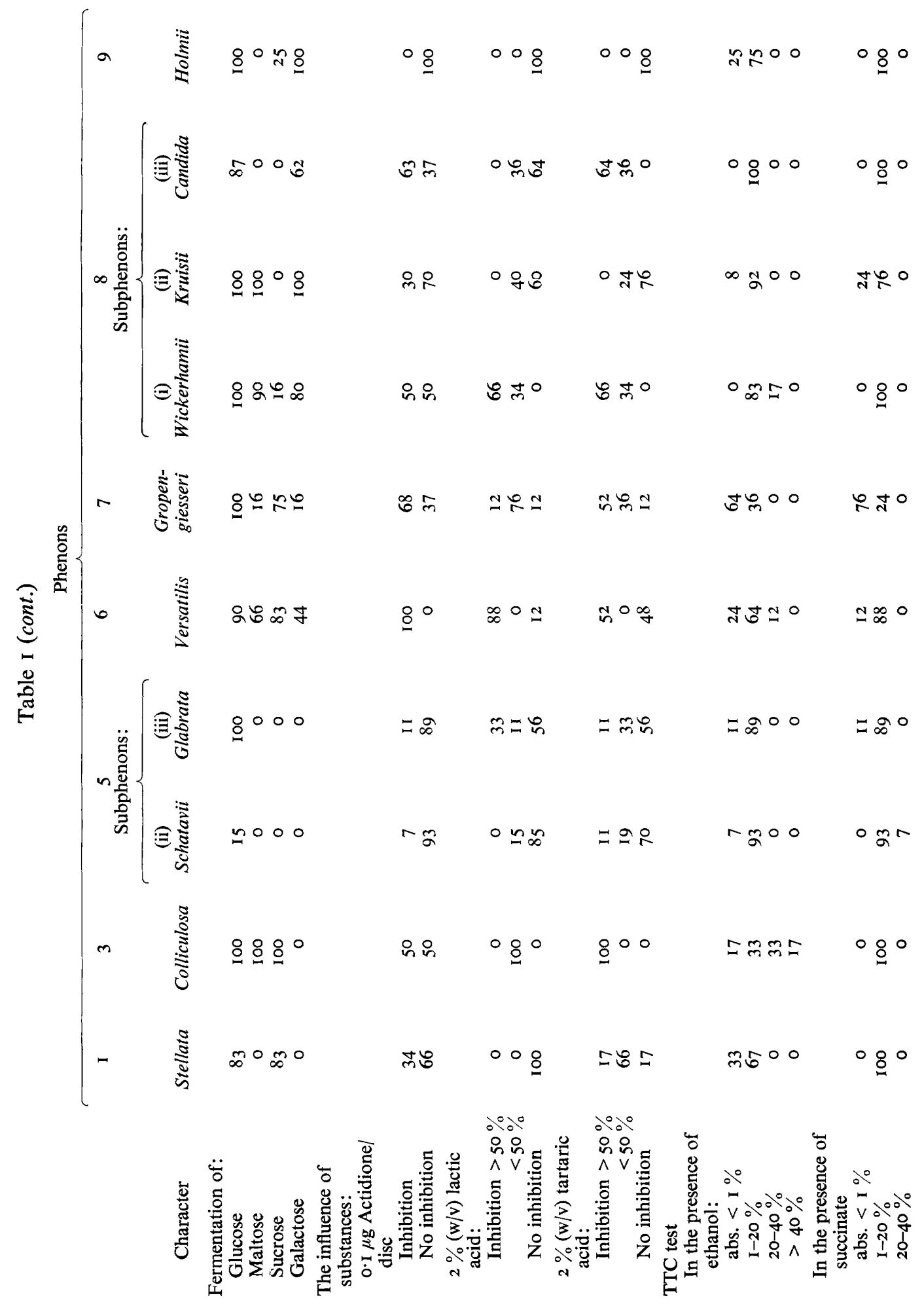




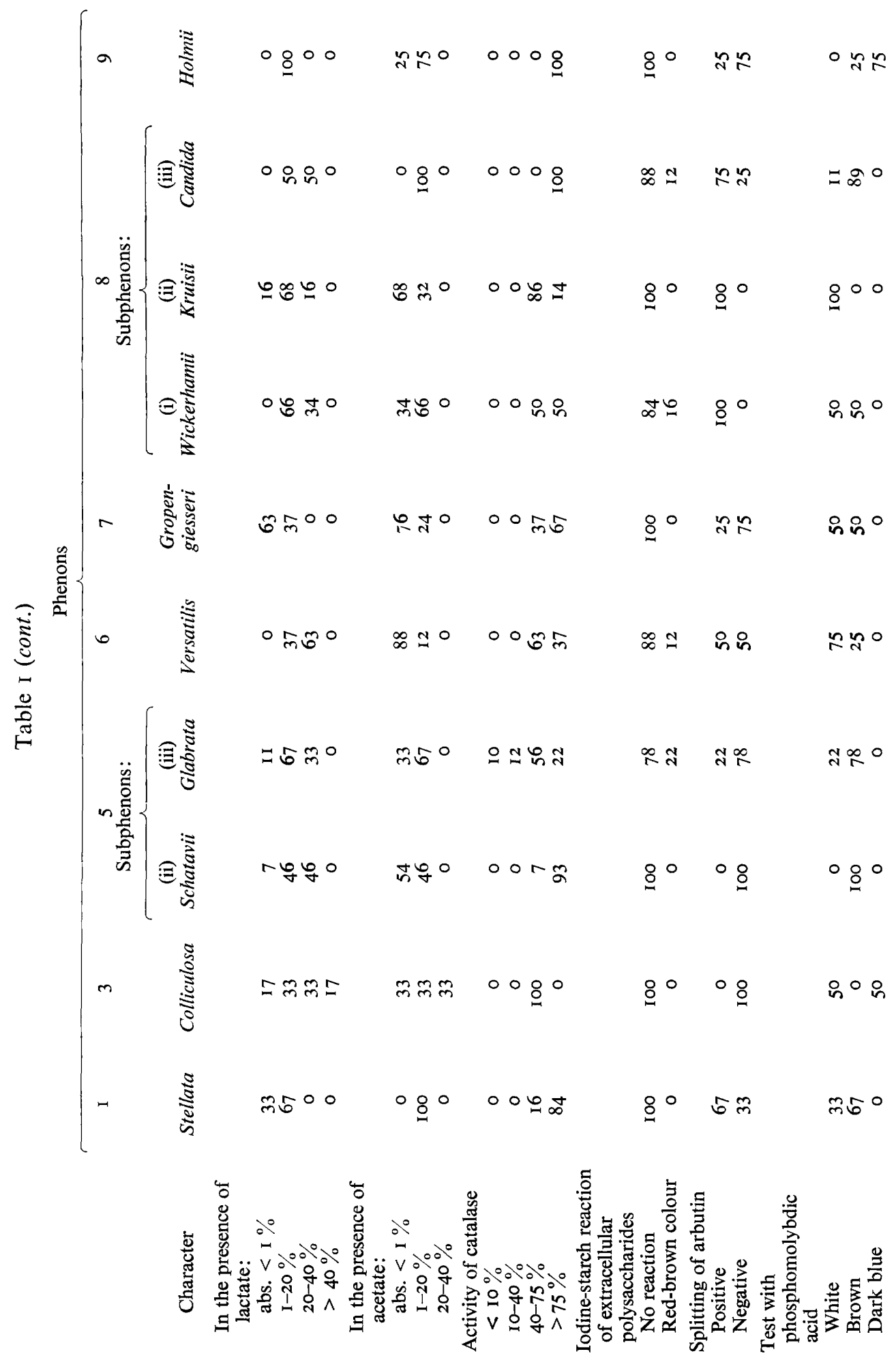


A. KOCKOVÁ-KRATOCHVÍLOVÁ

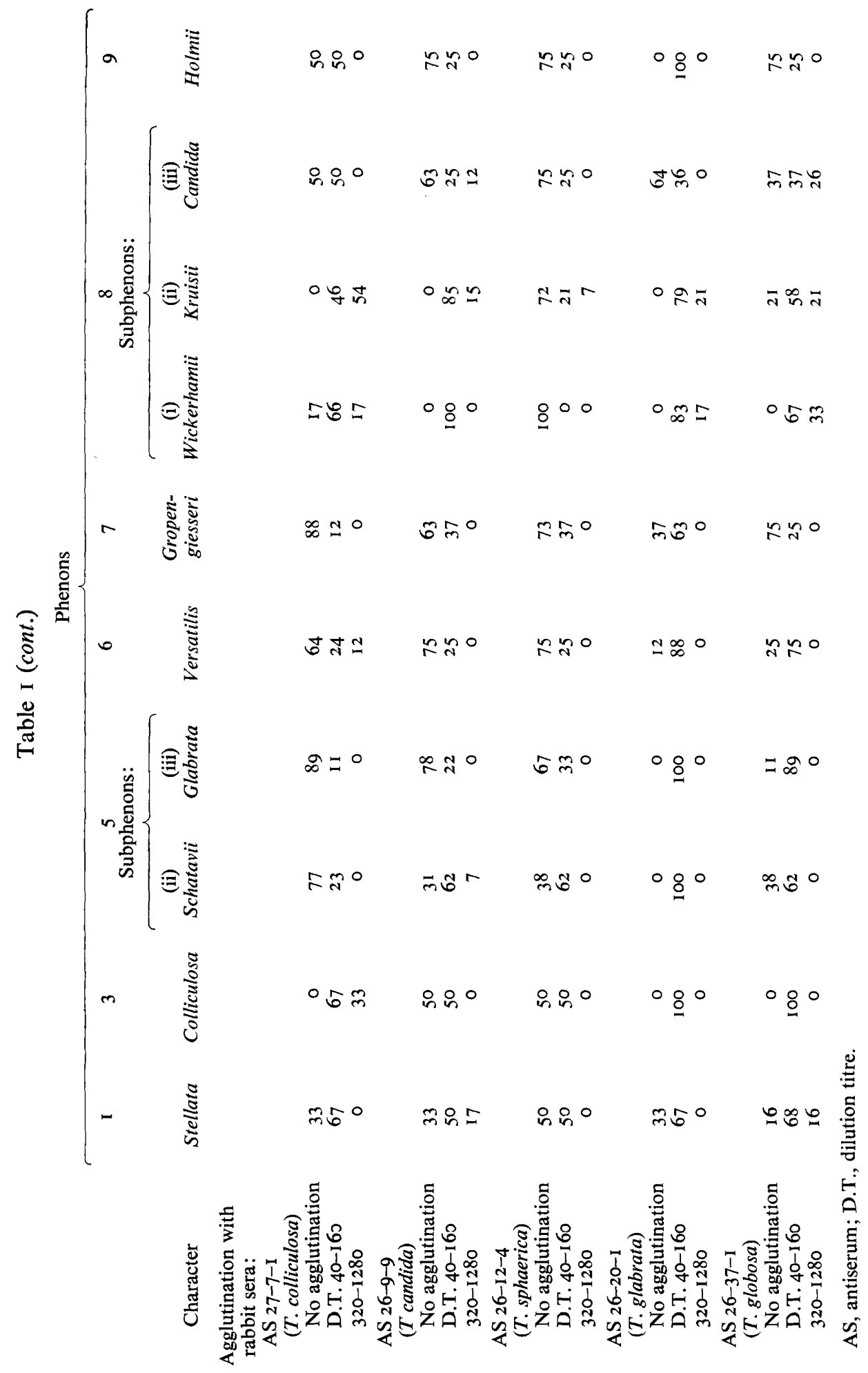


T. colliculosa (Rosa, South Slovakia, I958); CCY 26-7-5, T. colliculosa (BU ČSAV, 626, I958); and CCY 26-7-6, T. colliculosa (CBS I33, I964).

Cells were globose to short-oval; S/V quotients were typical for haploid or diploid cells. Sediment was produced in liquid media. Giant colonies were smooth, glistening or semidull; the growth rate was moderate. Strains grew well at $5{ }^{\circ} \mathrm{C}$, but not at $42{ }^{\circ} \mathrm{C}$. They tolerated $\mathrm{I}$ to $\mathrm{I} 2 \%(\mathrm{w} / \mathrm{v})$ ethanol in the medium. Osmophily was high. They did not require external vitamins for growth. Sedimentation and autolysis were slow. The growth inhibition by $0 . I \mu \mathrm{g}$ actidione/disc was variable: $2 \%(\mathrm{w} / \mathrm{v})$ lactic acid inhibited the growth strongly, $2 \%(\mathrm{w} / \mathrm{v})$ tartaric acid weakly. The TTC test was positive in the presence of succinate. Catalase activity was moderate. The phosphomolybdic acid test gave a dark blue colour. All strains agglutinated with the serum prepared against Torulopsis colliculosa and $T$. glabrata. Glucose, sucrose and maltose were fermented; $\mathrm{KNO}_{3}$ was not assimilated.

\section{Phenon molischiana}

The strains assigned to the phenon molischiana were: CCY 26-8-I, Torulopsis molischiana (BU ČSAV 628, I958); and CCY 26-8-2, T. molischiana (CBS I 36, I964).

Cells were ovoid, and $\mathrm{S} / \mathrm{V}$ quotients were typical for haploid cells. Sediment and islets were produced in liquid media. Fast-growing giant colonies were smooth to mucous. The growth temperature range was 5 to $42{ }^{\circ} \mathrm{C}$. Strains tolerated $8 \%(\mathrm{w} / \mathrm{v})$ ethanol in the medium. Osmophily was low. They required vitamins for growth. Sedimentation and autolysis were slow. Strains were inhibited by $0^{\circ} \mathrm{I} \mu \mathrm{g}$ actidione/disc and weakly inhibited by $2 \%(\mathrm{w} / \mathrm{v})$ tartaric acid, but no inhibition was observed in the presence of $2 \%(\mathrm{w} / \mathrm{v})$ lactic acid. The TTC test was positive in the presence of succinate. Catalase activity was moderate. Arbutin was split. The strains agglutinated with sera prepared against Torulopsis candida and $T$. glabrata. Glucose was fermented; $\mathrm{KNO}_{3}$ was assimilated.

\section{Phenon pinus-schatavii-glabrata}

The strains assigned to the phenon pinus-schatavii-glabrata were: (i) CCY 26-24-I, Torulopsis pinus (IFO 074I, I958); CCY 26-24-2, T. pinus (CBS 970, I964); and CCY 26-3I-I, T. buffoni (CBS 2838, 1964). (ii) CCY 26-26-I, T. schatavii (Grifola montana; Dobroč, 1962); CCY 26-26-2, T. schatavii (Russula cyanocantha; Dobroč, I962); CCY 26-26-4, T. schatavii (Polyporus varius; Dobroč, I962); CCY 26-26-5, T. schatavii (Fomitopsis pinicola; Dobroč, I962); CCY 26-26-6, T. schatavii (Grifola montana; Dobroč, 1962); CCY 26-26-7, T. schatavii (Grifola sulphurea; Dobroč, 1962); CCA 26-26-8, T. schatavii (Russula integra; Dobroč, 1962); CCY 26-26-9, T. schatavii (Amylocystis lapponica; Dobroč, I962); CCY 26-2I-7, T. schatavii (originally as $T$. burgeffiana); CCY 26-20-I, T. glabrata (T. tsuchiya, Japan; no. 4-002, I962); CCY 26-20-4, T. glabrata (Fomitopsis pinicola; Dobroč, 1962); CCY 26-20-8, T. glabrata (Lactarius flexousus; Kuřrim, I962); and CCY 26-20-I3, T. glabrata (Flammula muricata; Omice-Střelice, 1962). (iii) CCY 26-20-2, T. glabrata (Amylocystis lapponica; Dobroč, I962); CCY 26-20-3, T. glabrata (Trametes abietina; Dobroč, 1962); CCY 26-20-5, T. glabrata (Fomitopsis pinicola; Dobroč, I962); CCY 26-20-6, T. glabrata (Phellinus hartigii; Dobroč, I962); CCY 26-20-9, T. glabrata (Lactarius flexuosus; Kuřim, I962); CCY 26-20-10, T. glabrata (Lactarius turpis; Kuřim, I962); and CCY 26-20-I1, T. glabrata (Amanita muscaria; Kư̌im, 1962).

Cells were small, globose to oval, and S/V quotients were typical for haploid strains. Sediment and islets were produced in liquid media. Growth temperature range was 5 to $42{ }^{\circ} \mathrm{C}$ with the exception of subphenon pinus, strains of which did not grow at $42{ }^{\circ} \mathrm{C}$. These strains tolerated various percentages of ethanol in the media: in the subphenon pinus, up to 
$16 \%(\mathrm{w} / \mathrm{v})$; in glabrata, $4 \%(\mathrm{w} / \mathrm{v})$ only. The majority of these strains required vitamins in the media for growth. Sedimentation and autolysis were slow. Neither $0 \cdot \mathrm{I} \mu \mathrm{g}$ actidione/disc, nor $2 \%(w / v)$ lactic and tartaric acid inhibited growth. The TTC test was positive in the presence of ethanol and succinate. Only some strains split arbutin. All strains of the subphenons glabrata and schatavii agglutinated with the serum prepared against Torulopsis glabrata, those of subphenon pinus with serum against $T$. colliculosa, $T$. sphaerica, $T$. candida and T. globosa. Strains of subphenon pinus did not ferment sugars; some strains of schatavii fermented glucose weakly, but all strains of glabrata fermented glucose. $\mathrm{KNO}_{3}$ was not assimilated. A detailed description of $T$. schatavii is given in our previous paper (KockováKratochvílová \& Ondrušová, 1971).

\section{Phenon versatilis}

The strains assigned to the phenon versatilis were: CCY 26-46-I, Torulopsis osloensis (CBS 2752, I964); CCY 26-42-1, T. miso alfa (CBS 2032, I964); CCY 26-50-I, T. versatilis (CBS 1752, I964); CCY 26-33-I, T. citrus (CBS 2987, 1964); CCY 26-35-I, T. ernobii (CBS I737, 1964); CCY 26-27--I, T. anomala (CBS I73I, 1964); and CCY 26-38-I, T. halophilus (CBS 4019, I964).

Cells were globose, ovoid or elongate; S/V quotients were variable. Sediment or islets were formed in liquid media. Giant colonies were smooth or semi-rough, growing fast. Some strains grew at $5{ }^{\circ} \mathrm{C}$, some at $42{ }^{\circ} \mathrm{C}$, but mostly the temperature range for growth was narrow. Strains tolerated $16 \%(\mathrm{w} / \mathrm{v})$ ethanol in the medium; osmophily was high. The majority of strains needed external vitamins for growth. Sedimentation and autolysis were slow. Growth was inhibited by $0 . \mathrm{I} \mu \mathrm{g}$ actidione/disc, and $2 \%(\mathrm{w} / \mathrm{v})$ lactic and tartaric acids were weakly inhibitory. The TTC test was usually positive in the presence of succinate and acetate. Catalase activity was moderate. Serological reactions were variable. Fermentation of sugars was also variable; $\mathrm{KNO}_{3}$ was assimilated by the majority of strains.

\section{Phenon gropengiesseri}

The strains assigned to the phenon gropengiesseri were: CCY 26-28-1, Torulopsis apis (CBS 2674, 1964); CCY 26-29-I, T. apicola (CBS 2868, 1964); CCY 26-44-I, T. nodaensis (CBS 3094, 1964); CCY 26-25-1, T. gropengiesseri (BUČSAV 0626, I958); CCY 26-25-2, $T$. gropengiesseri (CBS I 56, I964); CCY 26-10-1, T. stellata var. cambresieri (South Slovakia, JS 24I, 1958); CCY 26-I0-2, T. stellata var. cambresieri (South Slovakia, JS 240, 1958); and CCY 26-40-I, T. magnoliae (CBS I66, I964).

Cells were globose, ovoid or elongate; S/V quotients were mostly similar to haploid strains. Pseudomycelium was absent or rudimentary. Sediment or islets were formed on the surface of liquid media. Giant colonies were smooth to semi-dull, growing slowly. These strains grew well at $28{ }^{\circ} \mathrm{C}$, half of them grew at $5{ }^{\circ} \mathrm{C}$, but none at $42{ }^{\circ} \mathrm{C}$. They all tolerated $8 \%(\mathrm{w} / \mathrm{v})$ ethanol in the medium, and some single strains up to $\mathrm{I} 6 \%(\mathrm{w} / \mathrm{v})$. The osmophily was high. They needed vitamins for growth. Sedimentation was fast, autolysis slow. Growth was strongly inhibited by $0 . \mathrm{I} \mu \mathrm{g}$ actidione/disc, and by $2 \%(\mathrm{w} / \mathrm{v})$ lactic and tartaric acid. Catalase activity was high. Arbutin was split. Serological reactions were variable. External polysaccharides were characterized as heteropolysaccharides, mostly galactomannans (Spencer, Gorin \& Tulloch, 1970). $\mathrm{KNO}_{3}$ was not assimilated. Glucose and sucrose were fermented, and some strains fermented maltose and galactose. 


\section{Phenon wickerhamii-kruisii-candida}

The strains assigned to the phenon wickerhamii-kruisii-candida were: (i) CCY 26-5I-I, Torulopsis wickerhamii (CBS 2928, 1964); CCY 29-9-10, T. candida (Russula veternosa; Kuřim, I962); CCY 26-49-I, T. saccharini (CBS 45I4, I964); CCY 26-49-2, T. saccharini (Santa Maria Az8, 1964); CCY 26-I7-I, T. minor (CBS, I947); and CCY 26-35-2, T. ernobii (Boletus satanas; Kur̆im, 1962). (ii) CCY 26-19-3, T. kruisii (Amanita muscaria; Kuřim, 1962); CCY 26-19-4, T. kruisii (Boletus satanas; Kuřim, I962); CCY 26-19-5, T. kruisii (Lactarius vellereus; Kuřim, I962); CCY 26-I9-6, T. kruisii (L. vellereus; Kuřim, I962); CCY 26-19-7, T. kruisii (B. purpureus; Kuřim, I962); CCY 26-19-8, T. kruisii (Russula chloroides; Kuřim, 1962); CCY 26-19-9, T. kruisii (R. lepida; Kuřim, 1962); CCY 26-19-10, $T$. kruisii (R. vesca; Kuřim, I962); CCY 26-I9-I I, T. kruisii (R. chloroides; Kur̆im, I962); CCY 26-19-12, T. kruisii (Paxillus atramentosus; Kuřim, 1962); CCY 26-19-13, T. kruisii (A. porphyrea; Kuřim, I962); CCY 26-I9-I4, T. kruisii (R. veternosa; Kuřim, I962); CCY 26-I9-15, T. kruisii (Crepidotus mollis; Kuřim, I962); and CCY 26-19-I, T. famata (CBS, 1947). (iii) CCY 26-9-I, T. candida (acorns; South Slovakia, I958); CCY 26-9-2, T. candida (grapes; South Slovakia, 1958); CCY 26-9-3, T. candida (CBS, 1947); CCY 26-9-4, T. candida (South Slovakia, I959); CCY 26-9-5, T. candida (South Slovakia, I959); CCY 26-9-6, T. candida (South Slovakia, I959); CCY 26-9-8, T. candida (BUČSAV 62I/I, I958); and CCY 26-9-9, T. candida (CBS 940, 1964).

Cells were globose, oval to elongate; $\mathrm{S} / \mathrm{V}$ quotients were similar to haploid strains, except for the subphenon candida where they were similar to diploid cells. Pseudomycelium was absent or rudimentary. Islets were formed on liquid media. Giant colonies were smooth and fast growing, except in the candida group where they were semi-dull to rough. These strains grew well at $5{ }^{\circ} \mathrm{C}$ and $28{ }^{\circ} \mathrm{C}$ but not at $42{ }^{\circ} \mathrm{C}$; some exceptions were again found in the candida group. They varied in their tolerance of ethanol in the medium: maximal concentration was $\mathrm{I} 6 \%(\mathrm{w} / \mathrm{v})$ in the group wickerhamii, $\mathrm{I} 2 \%(\mathrm{w} / \mathrm{v})$ in candida and $8 \%(\mathrm{w} / \mathrm{v})$ in the kruisii group. Osmophily was high. Most strains needed vitamins for growth. Sedimentation and autolysis were slow. Some chlamydospores similar to those of Candida pulcherrima were found in the candida group. The sensitivity to actidione, lactic acid and tartaric acid was variable. The TTC test was positive in the presence of succinate in the subphenon wickerhamii, in the presence of ethanol in the kruisii group, and of ethanol, succinate and acetate in the candida subphenon. Catalase activity was high. Arbutin was usually split. All strains of the subphenon wickerhamii agglutinated with sera prepared against Torulopsis candida or $T$. glabrata, none reacted with the serum against $T$. sphaerica. All strains of the subphenon kruisii agglutinated with sera prepared against $T$. colliculosa, $T$. candida and $T$. glabrata. The agglutination of the group candida with all investigated sera was variable. The subphenon wickerhamii fermented glucose, some strains fermented galactose, maltose and sucrose, and other subphenons only glucose and galactose. With the exception of some strains in the wickerhamii subphenon, $\mathrm{KNO}_{3}$ was not assimilated. A detailed description of the phenon kruisii is given in our previous paper (Kocková-Kratochvílová \& Ondrušová, 1971).

\section{Phenon holmii}

The strains assigned to the phenon holmii were: CCY 26-I6-I, Torulopsis holmii (CBS, I947); CCY 26-I6-2, T. holmii (BUČSAV 627, 1958); CCY 26-I6-3, T. holmii (CBS I35, I964); and CCY 26-I 5-2, T. sake (CBS I 59, I964).

Cells were large and mostly elongate; S/V quotients were typical for diploid strains. Pseudomycelium was absent or rudimentary. The only sediment existed in liquid media. 
Giant colonies were semi-dull to rough and growth rate was slow. They grew well at $28{ }^{\circ} \mathrm{C}$ but no growth was observed at 5 or $42{ }^{\circ} \mathrm{C}$. These strains tolerated $8 \%(\mathrm{w} / \mathrm{v})$ ethanol in the medium; osmophily was high. They required vitamins for growth. Growth was not inhibited by $0 . \mathrm{I} \mu \mathrm{g}$ actidione/disc, or by $2 \%(\mathrm{w} / \mathrm{v})$ lactic and tartaric acid; the TTC test was positive in the presence of succinate and lactate. Catalase activity was high. Splitting of arbutin was variable. The phosphomolybdic acid test gave a dark blue colour. All strains were agglutinated with the serum prepared against Torulopsis glabrata. They fermented glucose, galactose and sucrose, and did not assimilate $\mathrm{KNO}_{3}$.

\section{The intermediate and marginal strains}

There are five individual strains: CCY 26-3-I, Torulopsis etchellsii (CBS I75I, BUČSAV 0624, I958); CCY 26-22-I, T. ingeniosa (di Menna, I959); CCY 26-26-II, T. inconspicua (CBS I 80, I964); CCY 26-43-I, T. nitratophila (CBS 2027, 1964); and CCY 26-45-I, $T$. norvegica (CBS 4239, 1964).

The positions of these strains in the dendrogram were as follows: Torulopsis norvegica between the phenons schatavii and glabrata; T. inconspicua between the phenons $C$ and versatilis; $T$. etchellsii between the phenons versatilis and gropengiesseri; $T$. nitratophila between wickerhamii and kruisii; $T$. ingeniosa near $T$. pseudoaeria, which was excluded by transfer to Cryptococcus. Two strains of T. aeria, CCY 26-23-I and CCY 26-23-2, were also transferred to the genus Cryptococcus. These two strains and $T$. ingeniosa were the only strains showing urease activity.

\section{The excluded strains}

These strains, whose description did not agree with the definition of the genus Torulopsis, formed four groups, designated A, B, C and D (Fig. I).

The strains assigned to group A were: CCY 26-6-3, Torulopsis dattila var. rohrbachense (CBS 2254, I964); CCY 26-I 5-I, T. sake (BUČSAV 625, I958); CCY 26-I4-I, T. xylinusa (BUČSAV 0627, I958); CCY 26-I0-4, T. stellata var. cambresieri (no. XII, South Slovakia, 1958); CCY 26-I 8-I, T. lipofera (CBS, I947); CCY 26-I-I, T. utilis (LVHCH, 1943); CCY 26-I-2, T. utilis (LVHCH, I943); and CCY 26-I-4, T. utilis (LVHCH, I943). These strains formed rudimentary or well-developed pseudomycelium, and were therefore thought to be Candida spp.

The strains assigned to group B were: CCY 26-2-I, Torulopsis casei (LVHCH, I943); CCY 26-2-2, T. casei (LVHCH, I943); CCY 26-2-3, T. casei (LVHCH, 1943); CCY 26-12-I, T. sphaerica (CBS, I947); CCY 26-I 2-2, T. sphaerica (BU ČSAV 622/2, 1958); CCY 26-12-3, T. sphaerica (BUČSAV 622/I, I958); and CCY 26-I 2-4, T. sphaerica (CBS I 4I, 1964). These strains were thought to be related to the genus Kluyveromyces. Their detailed description is given in our previous paper (Kocková-Kratochvílová, Blagodatskaja \& Hronská, 1972).

The strains assigned to group Cwere: CCY 26-20-7, Torulopsis glabrata (Amanita caesarea; Kưrim, I962); CCY 26-20-I2, T. glabrata (Flammula muricata; Omice-Střelice, 1962); CCY 26-20-I4, T. glabrata (Flammula muricata; Omice-Střelice, 1962); CCY 26-20-15, T. glabrata (Lacrymaria velutina; Omice-Strelice, I962); CCY 26-20-I6, T. glabrata (Hydnum coralloides; Ž đ̌ár, I962); CCY 26-20-17, T. glabrata (Anthrordra mollis; Žď́r, 1962); CCY 26-20-18, T. glabrata (Anthrordra mollis; Žd̆ár, 1962); CCY 26-20-19, T. glabrata (Anthrordra mollis; Ždár, 1962); and CCY 26-21-3, T. burgeffiana (Benda, Würtzburg, I963). They formed pseudomycelium and were thought to be Candida spp.

The strains assigned to the group D were: CCY 26-2I-I, Torulopsis burgeffiana (Benda; Würtzburg, no. b I, I963); CCY 26-2I-2, T. burgeffiana (Benda; Würtzburg, no. b2, I963); 
CCY 26-2I-4, T. burgeffiana (Benda; Würtzburg, no. b4, I963); CCY 26-2I-5, T. burgeffiana (Benda; Würtzburg, no. b5, 1963); and CCY 26-2I-6, T. burgeffiana (Benda; Würtzburg, no. b6, 1963). These strains produced chlamydospores similar to those of Candida pulcherrima. We transferred these strains to the species C. pulcherrima or to its perfect form Metschnikowia pulcherrima.

\section{DISCUSSION}

The strains used were received from other collections or were isolated from a variety of natural habitats and identified. Some of these strains had been maintained in pure culture in our collection for a long time, e.g. six strains since 1943 and seven since 1947. Consequently, some characters had altered and after the re-evaluation did not agree with the original description or with the standard description given by Lodder (1970). However, the names under which they were described or received originally were retained.

Among the II 8 strains included in Fig. I, 94 produced budding cells, but none formed sexual spores or pseudomycelium; these strains are therefore valid strains of the genus Torulopsis. The recent identification of species of this genus is based on differences in fermentation and assimilation abilities of various sugars (Lodder, I970). We proposed (KockováKratochvílová \& Vojtková-Lepšíková, 196I) sorting the yeast strains into four types according to their ability to ferment maltose and sucrose. Table 2 shows how the nine phenons studied are classified into these fermentation types.

We have computed the frequency of occurrence of individual fermentation types and their abilities to assimilate various sugars, for the whole set studied (Table 3). We have done likewise for the set of 36 species accepted by Lodder (1970), and similar results were obtained. We therefore consider that the set of strains chosen for our investigation adequately represents the whole genus Torulopsis. According to the frequencies with which the assimilation of sugars occurs in this genus, sugars can be sorted into five groups. (I) Frequency $=75$ to $100 \%$ : glucose $(100 \%)$, galactose $(79 \cdot 3 \%)$ and mannitol $(73.7 \%)$. (2) Frequency $=50$ to $75 \%$ : maltose $(67.9 \%$ ), trehalose $(64.5 \%)$ and sucrose $(62 \cdot 8 \%)$. (3) Frequency $=25$ to $50 \%$ : xylose $(4 \mathrm{I} \cdot 5 \%)$, cellobiose $(37 \cdot 7 \%$ ) and ribotol $(34 \cdot 3 \%)$. (4) Frequency $=$ Io to $25 \%$ : melizitose $(18.7 \%)$, sorbose $(18.2 \%)$ and arabitol $(18.0 \%)$. (5) Frequency $<10 \%$ : melibiose $(6.5 \%)$ and lactose $(5 \cdot 3 \%)$.

We have compared this sorting with that of fermentation types, taking into consideration the phylogenetical development:

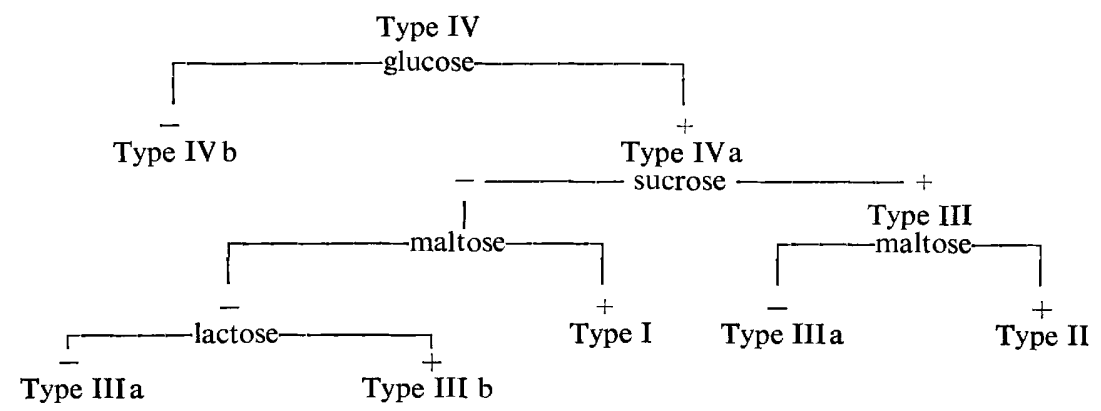

According to both assimilative and fermentative expressions, four different phylogenetic lines could be constructed: (A) Strains not fermenting galactose, i.e. (I) phenons no. I, 2, 3, 4, and (2) phenon no. 5; and (B) Strains fermenting galactose, i.e. (3) phenon no. 6, 7, and (4) phenons no. 8, 9 (see Table 3). 
A. KOCKOVÁ-KRATOCHVÍLOVÁ

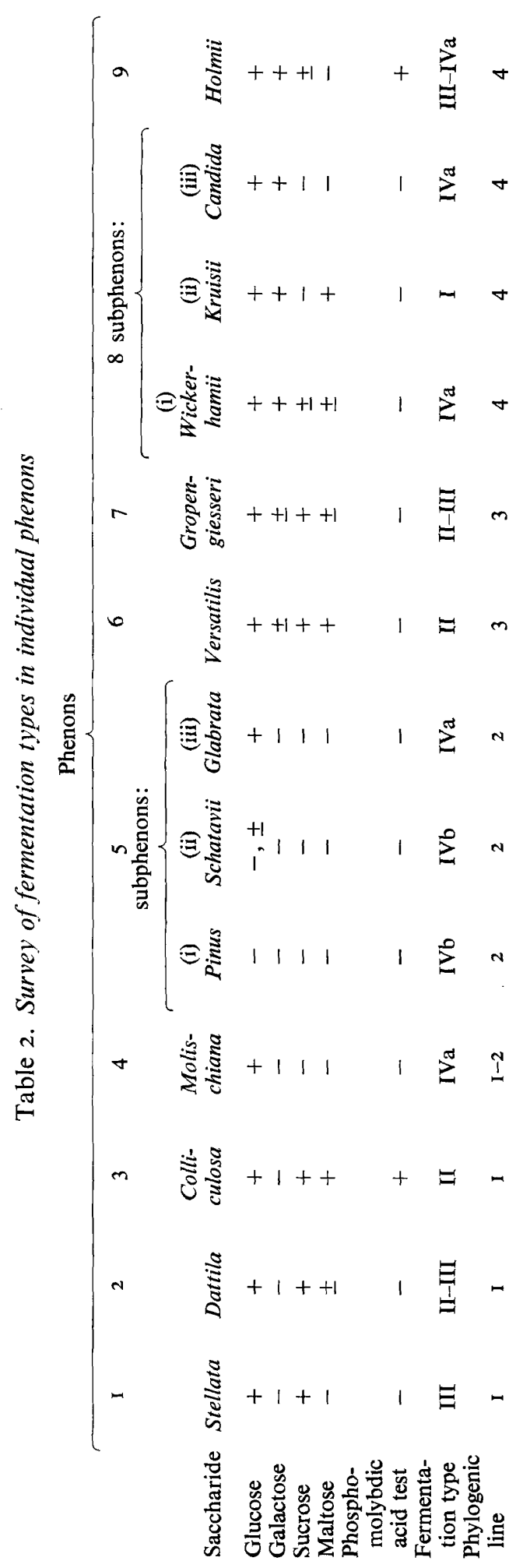


Table 3. Frequency of natural occurrence of Torulopsis strains of various fermentation types and their assimilation

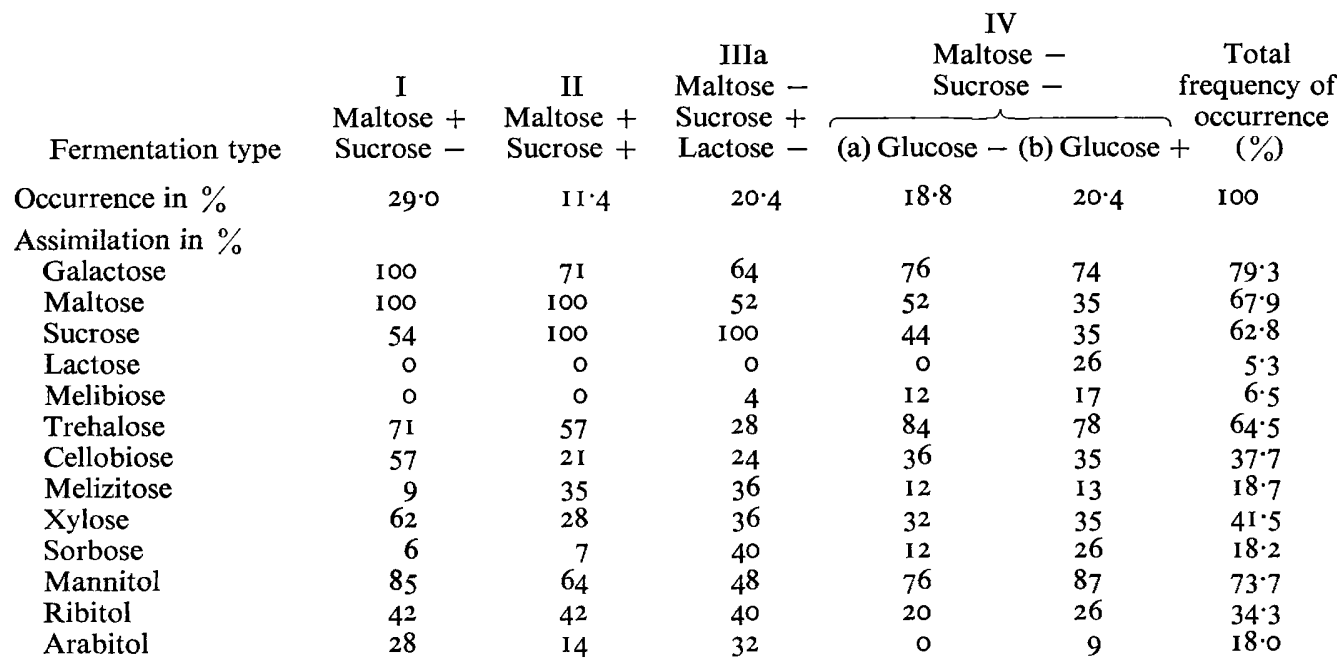

Table 4. GC content in DNA of individual phenons

No. of the group

(I)

(2)

(3)

(4)

(5)
$\mathrm{GC}$ content
$(\mathrm{mol} \%)$

$<35$

35-9

39-44

$44-50$

$>50$
Name and no. of the phenon

Holmii (9)

Wickerhamii-kruisii-candida (8)

Pinus-schatavii-glabrata (5)

Stellata (I)

Dattila (2)

Colliculosa (3)

Molischiana (4)

Versatilis (6)

Gropengiesseri (7)
Name of individual species

Torulopsis nitratophila (8)

$T$. norvegica (5)

T. inconspicua (5-6)

T. etchellsii (6-7)

We have compared our results with those of Nakase \& Komagata (1971), obtained from analyses of GC content in DNA. Altogether, the 68 strains of the genus Torulopsis examined formed a heterogeneous set. Thus the frequency distribution gave a histogram with five peaks, which divided the observed phenons into five groups (see Table 4). These five groups may represent monophyletic groups, which could be very helpful in the search for perfect forms among Ascomycetes and Basidiomycetes. In our previous paper (Kocková-Kratochvílová \& Nakase, 197I) we compared species of the genus Saccharomyces, the frequency distribution of which was quite normal with a mean mol $\%$ of GC $36 \cdot 75$ and a S.D. of $\mathrm{I} \cdot 96$. Numerical classification of the genus Saccharomyces revealed two different clusters; the first belongs to the genus Saccharomyces sensu stricto and the second to species originally described as Zygosaccharomyces. The range of GC contents of Saccharomyces sensu stricto was $36 \cdot \mathrm{I}$ to $38 \cdot 0$, while for the second cluster it was $36 \cdot 6$ to $42 \cdot 0$. Thus the range of GC content of the genus Saccharomyces slightly overlaps with that of the genus Torulopsis, for which it is 32.4 to 60.0 . Taking into consideration the fermentation ability of both genera, the possibility of common phylogenetical origin becomes slight. In contrast, a common 
origin for Torulopsis species and the second cluster, Zygosaccharomyces, becomes more likely. The comparison with other perfect genera will be discussed in our future studies.

After we had completed this study some new species were described: Torulopsis dendrica, $T$. philyla, $T$. silvatica, $T$. insectalens and $T$. nemodendra by van der Walt, Scott \& Van der Klift (197I) and T. fragaria by Barnett \& Buhagiar (197I), which could be included into the heterogeneous phenon pinus-schatavii-glabrata. T. bombicola, described by Spencer et al. (I970) is similar to the phenon gropengiesseri, characterized by the presence of heteropolysaccharides.

In conclusion, it can be emphasized that the grouping of species on the basis of their phenetic similarities can considerably facilitate future search for perfect forms of Torulopsis species.

\section{REFERENCES}

BARnEtT, J. A. \& BUHAGiar, R. W. M. (1971). Torulopsis fragaria species nova, a yeast from fruit. Journal of General Microbiology 67, 233-238.

CAMPBELl, I. (1971). Numerical taxonomy of various genera of yeasts. Journal of General Microbiology 67, 223-23I.

Goodfellow, M. (197I). Numerical taxonomy of some Nocardioform bacteria. Journal of General Microbiology 69, 33-80.

Kocková-Kratochvílová, A., Blagodatskaja, V. \& Hronská, L. (1972). The Grouping of the Species within the Genus Kluyveromyces van der Walt. Yeasts, Models in Science and Technics. Bratislava: Slovak Academy of Science.

Kocková-Kratochvíloví, A. \& NaKase, T. (I97I). Vergleichende Taxonomie der Gattung Saccharomyces (Meyen) Reess. Zeitschrift für allgemeine Mikrobiologie II, 35-38.

KockovÁ-Kratochvíloví, A. \& ONDRUšovÁ, D. (1971). Torulopsisarten aus den Oberflächen höherer Pilze. Biológia 26, 477-485.

Kocková-Kratochvíloví, A., Petrovoví, T., Šandula, J. \& Hronské, L. (1964). A contribution to the ecology of yeast-like microorganisms. Yeast-like microorganisms from the surface of agarics from the virgin forest in Dobroč. Česká mykologie 18, $9 \mathrm{I}-98$ (in Slovak).

Kocková-Kratochvílová, A., Šandula, J., Vojtková, Lepšíková, A., Sedlárová, L. \& Kasmanová, M. (1969). A taxometric Study of the Genus Saccharomyces (Meyen) Reess. II. Saccharomyces cerevisiae Hansen and Related Species. Biologické prace. Bratislava: Slovak Academy of Science.

Kocková-Kratochvílová, A., Šmarda, F. \& Pokorná, M. (1965). A contribution to the ecology of yeastlike microorganisms. Yeast-like microorganisms from the surface of agarics from Bohemian-Moravian highland. Česká mykologie r9, I I4-I 20 (in Slovak).

Kocková-Kratochvíloví, A. \& VoJTKová-Lepšíkoví, A. (1961). Über die Bedeutung von vier Gärungstypen für die Identifizierung der Hefen. Brauwissenschaft $\mathbf{1 4}_{4}$, 2 I0-2 I 5.

LoDDer, J. (1970). The Yeasts, a Taxonomic Study. Amsterdam: North-Holland Publishing.

Nakase, T. \& Komagata, K. (197I). Significance of DNA base composition in the classification of yeast genus Torulopsis. Journal of General and Applied Microbiology 17, I61-166.

ONDRUŠoví, D. (1971). Numerical taxonomy of the genus Torulopsis. Thesis, Comenius University, Bratislava (in Slovak).

Spencer, J. F. T., GoRin, A. P. J. \& Tulloch, A. P. (1970). Torulopsis bombicola species nova. Antonie van Leeuwenkoek 36, 129-133.

SOKAL, R. R. \& Michener, C. D. (1958). A statistical method for evaluating systematic relationships. University of Kansas Science Bulletin 38, I409-I438.

Sokal, R. R. \& Sneath, P. H. A. (1963). Principles of Numerical Taxonomy. San Francisco and London: W. H. Freeman.

van DeR Walt, J. P., Scott, D. B. \& VAN DeR Klift, W. C. (I97I). Five new Torulopsis species from South African insect sources. Antonie van Leeuwenhoek 37, 46I-47I.

WiCKeRHAM, L. (1965). Opposite sexes as type specimen for heterothallic haploid yeasts. Taxon 14, I87-I88. 